\title{
Response of Black Ash Wetland Gaseous Soil Carbon Fluxes to a Simulated Emerald Ash Borer Infestation
}

\author{
Matthew Van Grinsven ${ }^{1,2, *(1)}$, Joseph Shannon 2 (i), Nicholas Bolton ${ }^{2}$, Joshua Davis 2 (D), \\ Nam Jin Noh ${ }^{2,3}$ (D), Joseph Wagenbrenner ${ }^{2,4}$, Randall Kolka ${ }^{5}$ and Thomas Pypker 6 \\ 1 Department of Earth, Environmental and Geographical Sciences, Northern Michigan University, Marquette, \\ MI 49855, USA \\ 2 School of Forest Resources \& Environmental Science, Michigan Technological University, Houghton, \\ MI 49931, USA; jpshanno@mtu.edu (J.S.); nwbolton@mtu.edu (N.B.); joshuad@mtu.edu (J.D.); \\ n.noh@westernsydney.edu.au (N.J.N.); jwagenbrenner@fs.fed.us (J.W.) \\ 3 Hawkesbury Institute for the Environment, Western Sydney University, Penrith, NSW 2753, Australia \\ 4 USDA Forest Service, Pacific Southwest Research Station, Arcata, CA 95521, USA \\ 5 USDA Forest Service, Northern Research Station, Grand Rapids, MN 55744, USA; rkolka@fs.fed.us \\ 6 Department of Natural Resource Sciences, Thompson Rivers University, Kamloops, BC V2C 0C8, Canada; \\ TPypker@tru.ca \\ * Correspondence: mvangrin@nmu.edu
}

Received: 31 March 2018; Accepted: 23 May 2018; Published: 4 June 2018

\begin{abstract}
The rapid and extensive expansion of emerald ash borer (EAB) in North America since 2002 may eliminate most existing ash stands, likely affecting critical ecosystem services associated with water and carbon cycling. To our knowledge, no studies have evaluated the coupled response of black ash (Fraxinus nigra Marsh.) wetland water tables, soil temperatures, and soil gas fluxes to an EAB infestation. Water table position, soil temperature, and soil $\mathrm{CO}_{2}$ and $\mathrm{CH}_{4}$ fluxes were monitored in nine depressional headwater black ash wetlands in northern Michigan. An EAB disturbance was simulated by girdling (girdle) or felling (ash-cut) all black ash trees with diameters greater than $2.5 \mathrm{~cm}$ within treated wetlands ( $n=3$ per treatment). Soil gas fluxes were sensitive to water table position, temperature, and disturbance. Soil $\mathrm{CO}_{2}$ fluxes were significantly higher, and high soil $\mathrm{CH}_{4}$ fluxes occurred more frequently in disturbed sites. Soil $\mathrm{CH}_{4}$ fluxes in ash-cut were marginally significantly higher than girdle during post-treatment, yet both were similar to control sites. The strong connection between depressional black ash wetland study sites and groundwater likely buffered the magnitude of disturbance-related impact on water tables and carbon cycling.
\end{abstract}

Keywords: forested wetlands; Fraxinus nigra; invasive pest disturbance; greenhouse gas fluxes; soil carbon; biogeosciences; $\mathrm{EAB}$

\section{Introduction}

Disturbance events are known to impact the natural function of wetland ecosystems by altering nutrient, carbon, energy, and hydrologic fluxes [1,2]. Recently, emerald ash borer (EAB) (Coleoptera: Buprestidae, Agrilus planipennis Fairmaire) was introduced as an invasive pest to ash (Fraxinus spp.) forests in North America [3]. Hundreds of millions of ash trees were estimated to have been killed in North America within the decade following the initial detection of EAB in southeastern Michigan in July $2002[4,5]$. The expansion of EAB results in significant economic costs [6,7] and causes significant perturbation to forest ecosystems $[5,8,9]$, and will likely continue to decimate existing ash stands throughout North America.

Forested wetlands sequester large quantities of carbon from the atmosphere [10], and their carbon storage capacity is largely a result of prolonged periods of elevated water table position 
that limits decomposition [11,12]. Forest and soil gaseous-carbon fluxes are sensitive to disturbance of overstory trees [13,14], and fluxes from wetland soils are also regulated by water table position and soil temperature $[15,16]$. Disturbance to the dominant living woody component of a forested wetland has been shown to affect wetland water table positions $[17,18]$ and may affect soil temperatures due to the decreased amount of transpiration and increased amount of incoming solar radiation. Ecohydrological responses to a simulated EAB infestation were evaluated concurrently with gaseous soil carbon fluxes in depressional black ash wetland study sites examined in this study. Significantly lower site transpiration, smaller rates of water table drawdown during the growing season, and elevated summertime water tables were detected following a simulated EAB infestation treatment in depressional black ash wetland study sites [17]. Similarly, mineral soil black ash wetlands in northern Minnesota treated with a simulated EAB infestation had significantly elevated water tables when compared to control sites [18]. Ultimately, wetland soil carbon pools and fluxes will be concomitantly influenced by overstory disturbance and by the response of water table position and soil temperature.

Most research on wetland carbon storage and fluxes has focused on boreal or sub-boreal peatland ecosystems dominated by Sphagnum species and sparse coniferous tree species $[19,20]$, yet large stores of carbon also exist in mixed deciduous forested wetlands with histic, histic-mineral, and mineral soils [21,22]. Histic-mineral and mineral soil wetlands are five times more abundant on earth's surface than histosol wetlands, and comprise an estimated $22 \%$ of the global wetland carbon pool $[10,23]$. Freshwater mineral soil wetlands may contain significant organic soil deposits (20 to $40 \mathrm{~cm}$ depth), and have been inconsistently classified as either peatlands or fresh water mineral soil wetlands in regional- or global-scale wetland carbon cycle studies [24]. To our knowledge, no studies have specifically examined carbon cycling processes in deciduous forested peatlands.

Biogeochemophysical conditions such as temperature, $\mathrm{pH}$, water table position, soil moisture, redox potential, and soil microbial communities affect the production and fluxes of gaseous soil carbon constituents $\left(\mathrm{CO}_{2}, \mathrm{CH}_{4}\right)$ [19]. There are complex relationships between soil microbial community composition, physical and chemical conditions, the quality of available organic matter, and rates of soil decomposition [25]. As a result, it is often difficult to separate the influences of individual biogeochemophysical factors from one another. Peatland decomposition processes have consistently been shown to be sensitive to both soil temperature and redox conditions [26,27].

Carbon dioxide fluxes from wetlands generally increase following episodic short-term water table fluctuations; however, the magnitude of the response can be highly variable [26]. Specifically, $\mathrm{CO}_{2}$ production and flux may increase following episodic water table fluctuations due to redox reaction-induced chemical breakdown and activation of exo-enzymes following short-term exposure to oxygen $[11,28,29]$. In contrast, the quality of organic substrate and presence of certain microbial communities can inhibit decomposition rates following episodic oxidation-state modifying events [19]. It is unclear how EAB-induced alteration of water tables may affect oxidation-reduction processes and ultimately decomposition rates in black ash wetlands.

Temperature controls on $\mathrm{CO}_{2}$ production from wetlands have been well documented in both field and laboratory settings $[15,30]$. In laboratory studies, a $10^{\circ} \mathrm{C}$ temperature increase resulted in a positive change in $\mathrm{CO}_{2}$ production $\left(\mathrm{Q}_{10}\right)$ of two- to threefold [15]. However, in situ $\mathrm{Q}_{10}$ values have been inconsistent across vertical and lateral gradients within peatlands [30,31]. The uncertainty associated with the response of $\mathrm{CO}_{2}$ production rates to experimental temperature manipulations in peatlands has likely resulted from the complexity of in situ biogeochemical conditions. Additionally, the need to characterize soil warming impacts on peatland ecosystems remains critical for the development of accurate global carbon cycle models [32]. Removal of the overstory following an EAB infestation may increase insolation, increase wetland soil temperatures, and ultimately alter gaseous carbon fluxes.

Similar to $\mathrm{CO}_{2}$ production and fluxes, there are high degrees of spatial and temporal variability associated with $\mathrm{CH}_{4}$ production and fluxes from peatland soils [33]. Because both fermentation and $\mathrm{CO}_{2}$ reduction processes occur under anoxic conditions, the location of production and fate of 
$\mathrm{CH}_{4}$ once produced are highly sensitive to water table position [34]. Specific physical and chemical conditions need to be present for methane production to occur. Among the most important of these is the combined depletion of oxygen and absence of other, more efficient electron acceptors (e.g., $\mathrm{NO}_{3}^{-}, \mathrm{Fe}^{3+}, \mathrm{Mn}^{4+}$, and $\mathrm{SO}_{4}^{2-}$ ) that must be present before methanogenesis and $\mathrm{CO}_{2}$ reduction can proceed $[28,35]$. The initiation or rate of methane production has also been shown to be sensitive to $\mathrm{pH}[36]$, temperature [15], and substrate quality and availability [19,37].

Due to the co-occurrence of methanogens and methanotrophs in peatland soils, water table position is the single most influential physical parameter that regulates the quantity of $\mathrm{CH}_{4}$ fluxes from the soil surface. Several studies have evaluated the response of $\mathrm{CH}_{4}$ fluxes in peatlands to temperature and water table conditions [33,38-40]. Yet, to our knowledge, no study has examined the relationship between water table, soil temperature, and soil $\mathrm{CO}_{2}$ and $\mathrm{CH}_{4}$ fluxes in deciduous forested peatlands, nor has any study evaluated the response of gaseous soil carbon fluxes to a simulated invasive pest disturbance in deciduous forested peatlands. Temperature-dependent incubation experiments of $\mathrm{CH}_{4}$ production in cores extracted from hummock, lawn, and hollow locations in a peatland in southwestern Scotland revealed that $\mathrm{CH}_{4}$ production was similar among sites, yet in situ $\mathrm{CH}_{4}$ fluxes were highly variable and closely associated with the position of the water table [33]. The response of water tables and soil temperatures to an EAB-induced disturbance in black ash (Fraxinus nigra Marsh.) wetlands will likely alter $\mathrm{CH}_{4}$ production processes, and ultimately the amount of $\mathrm{CH}_{4}$ emitted from the soil surface.

This study examines the relationship between, and the coupled response of, water table, soil temperature, and gaseous soil carbon fluxes within the context of the previously established altered hydrologic regime in depressional black ash wetlands. The specific objectives of this study were to (1) characterize the relationships between water table position, soil temperature, and soil $\mathrm{CO}_{2}$ and $\mathrm{CH}_{4}$ fluxes; and (2) evaluate the responses of soil temperature and gaseous soil carbon fluxes to disturbances in black ash wetlands. Ultimately, this study will augment the currently limited knowledge of carbon cycling processes in deciduous forested peatlands and examine the ecosystem-level implications of a looming emerald ash borer infestation. We hypothesize that (1) water table position and soil temperature will be major influences on soil $\mathrm{CO}_{2}$ and $\mathrm{CH}_{4}$ fluxes from these soils; (2) soil temperature will increase because of increased insolation in disturbed sites; (3) soil $\mathrm{CO}_{2}$ fluxes will increase with the increased soil temperature in disturbed sites; and (4) soil $\mathrm{CH}_{4}$ fluxes will be higher because of the expected increased temperatures and elevated water tables detected in response to a simulated EAB infestation.

\section{Materials and Methods}

\subsection{Study Area}

The Ottawa National Forest (ONF) is located in the western portion of the upper peninsula of Michigan, USA (Figure 1). The ONF contains approximately $525 \mathrm{~km}^{2}$ of wetlands within $4000 \mathrm{~km}^{2}$ of mixed-hardwood forested area. Based upon US Department of Agriculture Forest Service Forest Inventory Analysis data, it is estimated that $70 \%$ of the $180 \mathrm{~km}^{2}$ deciduous forested wetlands within the ONF are dominated by black ash [41].

Black ash wetlands in the ONF commonly occur as landform depressions surrounded by mixed-hardwood upland tree species such as sugar maple (Acer saccharum L.) and white pine (Pinus strobus L.). Other tree species, such as red maple (Acer rubrum L.), yellow birch (Betula alleghaniensis Britt.), balsam fir (Abies balsamea L. (Mill)), and white cedar (Thuja occidentalis L.), are common, though typically at low abundance within these black ash-dominated wetlands [42]. Shrub, fern, and sedge species are abundant but unevenly distributed in the understory.

Black ash wetland soils in this study were composed of woody peats. The study site soils were, on average, $75 \%$ organic matter and $47 \%$ organic carbon [17]. Peat thicknesses in the study sites ranged from $40 \mathrm{~cm}$ to greater than $690 \mathrm{~cm}$, with an average peat depth of $140 \mathrm{~cm}$. A clay lens or a poorly sorted 
clay loam was commonly detected at the bottom of the peat layer. Black ash wetlands in the ONF are also characterized by seasonally inundated conditions and commonly have discernible surface drainage outlet channels. Most soils in the ONF originate from glacial landforms and may exist as thin horizons overlying near-surface bedrock [43].

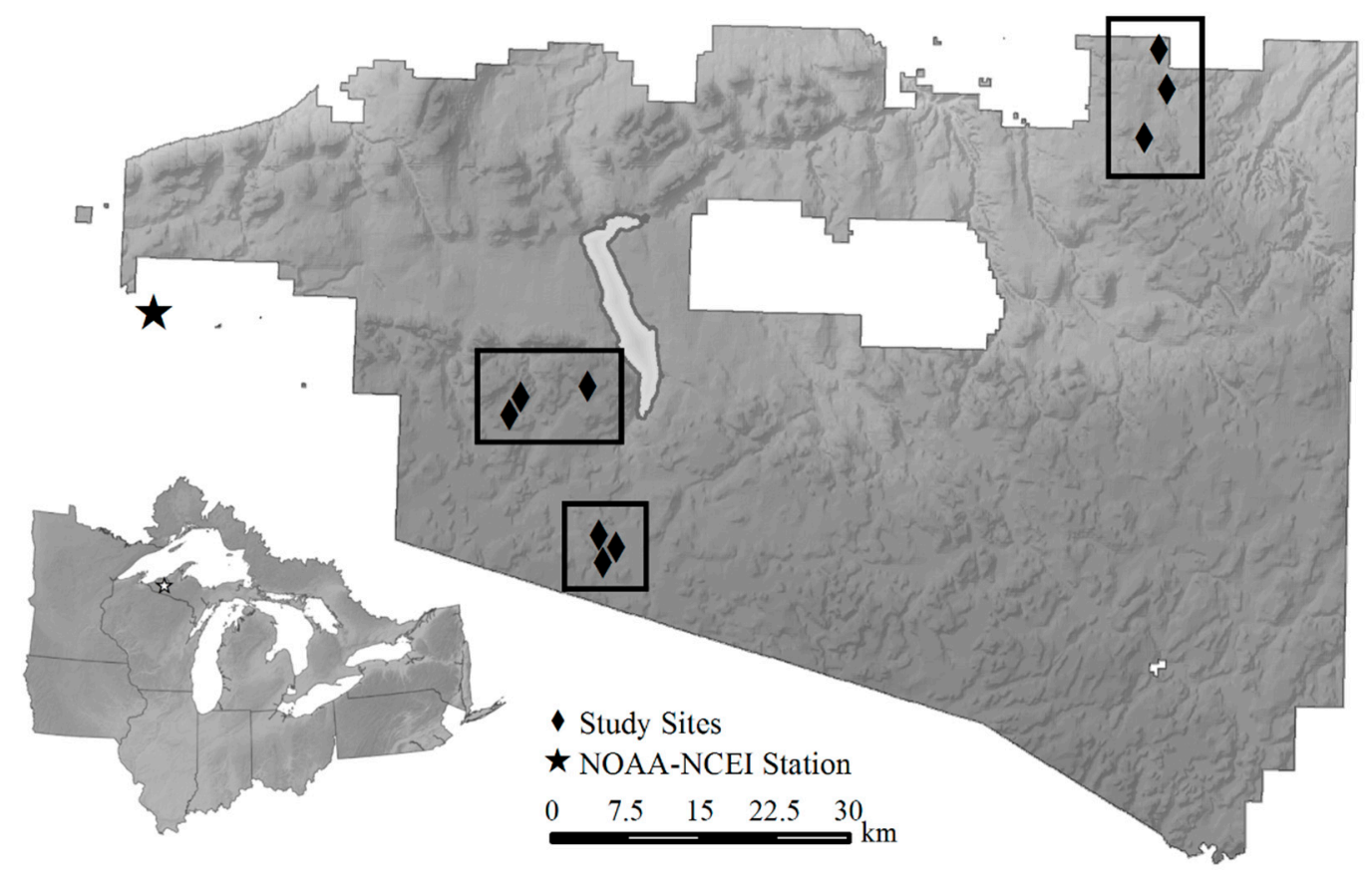

Figure 1. Map of Ottawa National Forest and black ash wetland study site locations within the Great Lakes region of North America (lower-left inset). Three geographically distinct locations (squares) were each subdivided into three treatment sites (diamonds). Regional precipitation data were obtained from the National Oceanic and Atmospheric Administration's National Centers for Environmental Information (NOAA-NCEI) [44] station in Ironwood, Michigan (star).

\subsection{Experimental Study Design}

Nine study sites within the Ottawa National Forest, ranging in size from 0.25 to $1.25 \mathrm{ha}$, were established in 2011 in isolated landform depressions within first-order watersheds [17] (Figure 1). Black ash basal area ranged from $26 \%$ to $85 \%$ of total basal area among study sites (mean $=66 \%$ ), and black ash was always the most abundant overstory tree [42]. Treatments were assigned randomly to 3 sites in 3 geographically distinct locations ( $n=3$ per treatment). Each distinct location included 1 untreated control, 1 girdle treatment, and 1 ash-cut treatment. A 1-year baseline data-collection period (2012) preceded the 2-year posttreatment monitoring period (2013-2014) of the study. The girdle treatment was used to simulate an active EAB infestation, wherein near-complete stand mortality could take 3-4 years [45]. In the girdled sites, all black ash trees greater than $2.5 \mathrm{~cm}$ in diameter at a height of $1.37 \mathrm{~m}$ had the bark, cambium, and phloem removed in a $15-30 \mathrm{~cm}$ tall circumferential band. The ash-cut treatment was used to simulate post-disturbance ecosystem conditions that might occur following complete loss of black ash from the overstory. In the ash-cut sites, all black ash trees greater than $2.5 \mathrm{~cm}$ at a height of $1.37 \mathrm{~m}$ were cut with chainsaws within $1.2 \mathrm{~m}$ of the soil surface during February 2013 and left on site. Treatments were applied between November 2012 and February 2013.

\subsection{Instrumentation and Monitoring}

Three random locations within each wetland site were determined with ArcGIS (Esri, Redlands, CA, USA), and were located at least $8 \mathrm{~m}$ from the wetland boundary. Two $13 \mathrm{~cm}$ tall gas collars constructed of $25.4 \mathrm{~cm}$ diameter PVC pipe were co-located $6 \mathrm{~m}$ apart and driven into the soil to a depth 
of $5 \mathrm{~cm}$ at each random location ( $n=6$ per site). Portable static dark chambers were used to measure both $\mathrm{CO}_{2}$ and $\mathrm{CH}_{4}$ fluxes [46,47], and were constructed of $25.4 \mathrm{~cm}$ ID PVC slip caps. A rim of closed cell foam was adhered to a PVC ring mounted within the chamber to ensure that there was an airtight seal between the gas collar and the chamber. The dark static chambers used to measure $\mathrm{CH}_{4}$ fluxes were equipped with a small fan to mix the chamber headspace [40]. When water table elevations exceeded $12 \mathrm{~cm}$ above the ground surface ( $6.3 \%$ of samples), high-density polyethylene extensions $50 \mathrm{~cm}$ long and $28 \mathrm{~cm}$ in diameter were used to connect the soil gas collar with the dark chamber.

$\mathrm{CO}_{2}$ and $\mathrm{CH}_{4}$ fluxes were measured at approximately monthly intervals during snow-free seasons (June-October) from 2012-2014. All measurements were collected on calm days between 11:00 and 17:30 $\mathrm{h}$ (EDT) to reduce insolation variability. Measurements were not collected if more than $6.4 \mathrm{~mm}$ of precipitation fell within the previous $8 \mathrm{~h}$. All 18 gas collars within 1 geographically distinct location were measured on the same day, and all sites were measured within a 4-day period each month.

An infrared gas analyzer (IRGA) (PP Systems EGM-4, PP Systems International Inc., Amesbury, MA, USA) was used with a static dark chamber, equipped with a small fan to mix the chamber headspace, to measure $\mathrm{CO}_{2}$ fluxes $[39,40] . \mathrm{CO}_{2}$ concentrations were logged by the IRGA at 2-3 s intervals for a total of $124 \mathrm{~s}$. The slope of $\mathrm{CO}_{2}$ concentration versus time $(t, \mathrm{~s})$ was estimated by linear regression [48]. Portions of nonlinear responses that occurred within the first $80 \mathrm{~s}$ of the measurement period were manually removed prior to calculating the slope. $\mathrm{CO}_{2}$ fluxes were then estimated according to Equation (1):

$$
\mathrm{CO}_{2} \text { Flux }=\frac{d \mathrm{CO}_{2}}{d \mathrm{t}} \times \frac{\mathrm{PV}}{\mathrm{ART}}
$$

where $\frac{d \mathrm{CO}_{2}}{d \mathrm{t}}$ is the slope from the regression, $\mathrm{P}$ is the atmospheric pressure (Pascal), $\mathrm{V}$ is the volume of the headspace within the chamber $\left(\mathrm{m}^{3}\right)$, A is the area of the soil encircled by the gas collar $\left(\mathrm{m}^{2}\right), \mathrm{R}$ is the gas constant $\left(\mathrm{J} \mathrm{K}^{-1} \mathrm{~mol}^{-1}\right)$, and $\mathrm{T}$ is the air temperature $(\mathrm{K})$. All dark chamber headspace volume estimates used in Equation (1) were corrected for water table position and extension headspace volume when necessary.

Gas-tight syringes were used to remove five $20 \mathrm{~mL}$ gas samples at consecutive 10 min intervals from each gas chamber [46]. Gas samples were immediately injected into pre-evacuated $6 \mathrm{~mL}$ EXETAINER $^{\circledR}$ glass vials (Labco Ltd., Lampeter, Wales, UK), and the septa were coated with $100 \%$ silicone for added leakage protection. Gas samples were analyzed within 30 days using gas chromatography (Varian 3800, Agilent Technologies Inc., Santa Clara, CA, USA) at Michigan Technological University's Hydrology and Wetlands Laboratory. As a quality-control measure, concentration standards were injected into EXETAINER ${ }^{\circledR}$ vials in the laboratory, transported to study sites during sampling excursions, and analyzed alongside field samples. The slope of the $\mathrm{CH}_{4}$ concentration versus time response was calculated using least-squares regression as described for $\mathrm{CO}_{2}$ above, and the slopes of the $\mathrm{CH}_{4}$ responses $\left(\frac{d \mathrm{CH}}{d t}\right)$ were used in place of $\frac{d \mathrm{CO}_{2}}{d t}$ in Equation (1) to estimate $\mathrm{CH}_{4}$ fluxes [15]. Gaseous soil carbon fluxes were reported as $\mathrm{mg} \mathrm{m}^{-2}$ day ${ }^{-1}$ of $\mathrm{CO}_{2}$ and $\mathrm{CH}_{4}$ molecules. Approximately $8 \%$ of samples with nonlinear slopes were flagged as possible human-induced ebullition events and were not included in the analysis.

Water levels were manually measured during monthly collection intervals and were recorded at 15 min intervals (Levelogger Junior M5, Solinst Canada Ltd., Georgetown, ON, Canada) in a steel monitoring well in each wetland [17]. The water level relative to the wetland soil surface $\left(W L_{m w},(\mathrm{~cm})\right)$ was calculated for each gas collar $\left(W L_{c o l},(\mathrm{~cm})\right)$ using total station surveyed elevations [17] at gas collars and metal monitoring wells, respectively. Soil temperature was measured within the gas collar $5 \mathrm{~cm}$ below the ground surface $\left(S T_{5 \mathrm{~cm}},{ }^{\circ} \mathrm{C}\right)$ immediately following each $\mathrm{CO}_{2}$ flux measurement. Soil temperature probes (107, Campbell Scientific, Logan, UT, USA) connected to on-site data loggers (CR800, Campbell Scientific) were installed to record every $15 \mathrm{~min}$ in all sites in 2011, but repeat damage by animals resulted in large amounts of missing data during 2012 and 2013. Temperature loggers (iButtons, Embedded Data Systems LLC, Lawrenceburg, KY, USA) set to record at $2 \mathrm{~h}$ intervals 
were subsequently installed $5 \mathrm{~cm}$ beneath the soil surface and within PVC solar shields located $1 \mathrm{~m}$ above the soil surface near the wetland monitoring well from June through November of 2014.

\subsection{Statistical Analysis}

Linear mixed-effects models (LMMs) were fit with the restricted maximum likelihood procedure in $\mathrm{R}[48,49]$ to assess the impact of water level, temperature, and treatment on soil $\mathrm{CO}_{2}$ and $\mathrm{CH}_{4}$ fluxes. Zero-concentration data $(n=400)$ from gas chromatograph calibration curves were used to determine the $0.36 \mathrm{ppm}$ instrument detection limit for $\mathrm{CH}_{4}$ [50]. Based upon the $40 \mathrm{~min}$ collection period, the lower detectable soil $\mathrm{CH}_{4}$ flux limit was determined to be $1.25\left(\mathrm{mg} \mathrm{m}^{-2} \mathrm{day}^{-1}\right)$. Approximately $20 \%$ of soil $\mathrm{CH}_{4}$ flux estimates were below the lower detection limit. Distribution parameters of the natural-log transformed $\mathrm{CH}_{4}$ flux data were calculated using maximum likelihood estimation to adjust for the censored values. Estimates for censored values were then imputed using random quantiles below the detection limit drawn from the fitted distribution as replacement values [51,52]. Following natural log-transformation of estimates of $\mathrm{CO}_{2}$ and $\mathrm{CH}_{4}$ from Equation (1), zero-mean assumptions of normality and homogeneity of variance were determined to be acceptable based on visual examination of residual plots for all linear mixed-effects models [48,49]. LMM methods were used to determine significance [53], the Tukey method was used to adjust p-values for all pairwise comparisons [54], and degrees of freedom were calculated according to the Kenward-Roger approximation [55]. Significance was reported where $p<0.05$, and marginal significance was reported where $p<0.1$. Following the transformation of $\mathrm{CO}_{2}$ and $\mathrm{CH}_{4}$ fluxes, the back-transformed regression equations took the form of Equation (2):

$$
C_{\text {Flux }}=\beta_{\circ} e^{\beta_{1} T_{\text {soil }}}
$$

where $\beta \circ$ is the back-transformed model intercept coefficient, and $\beta_{1}$ is the model slope coefficient.

Logged temperature and water level data from 2014 were used to test the response of maximum daily soil temperatures $\left(S T_{\max }\right)$ to maximum daily air temperatures $\left(A T_{\max }\right)$ and $W L_{m w}$. The influence of $W L_{m w}$ on the relationship between $S T_{\max }$ and $A T_{\max }$ was evaluated by comparing a two-level LMM $\left(A T_{\max } \cdot W L_{m w}\right)$ with a single-level LMM $\left(A T_{\max }\right)$, where $A T_{\max }$ and $W L_{m w}$ were used as fixed effects, and site and day were used as crossed random effects. Additionally, the response of $S T_{\max }$ to $A T_{\max }$, $W L_{m w}$, and treatment during the posttreatment study period was tested with a three-level LMM where $A T_{\max }, W L_{m w}$, and treatment were used as fixed effects, and site and day were used as crossed random effects.

LMM selection criteria, including the conditional variance $\left(r_{c}^{2}\right)$ and marginal variance $\left(r_{m}^{2}\right)$, the Akaike information criterion (AIC), the residual proportion change in variance (PCV), and residual standard error (RSE) were used to evaluate model performance [53,56]. Multivariate LMM response surfaces were predicted [57] by generating slopes for four water level positions: $10 \mathrm{~cm}$ above, $10 \mathrm{~cm}$ below, $30 \mathrm{~cm}$ below, and $50 \mathrm{~cm}$ below the wetland soil surface. Observations were binned with equidistant spacing between the four water level positions and used for visual interpretation only.

The influence of $W L_{c o l}$ on the relationship between soil gas flux and $S T_{5 \mathrm{~cm}}$ was evaluated by comparing a two-level LMM $\left(S T_{5 \mathrm{~cm}} \cdot W L_{c o l}\right)$ with a single-level LMM $\left(S T_{5 \mathrm{~cm}}\right)$ for $\mathrm{CO}_{2}$ and $\mathrm{CH}_{4}$, respectively (Table 1). Both $S T_{5 \mathrm{~cm}}$ and $W L_{c o l}$ were used as fixed effects, and correlated random intercepts and slopes were generated for each collar nested within site. Posttreatment $\mathrm{CO}_{2}$ and $\mathrm{CH}_{4}$ fluxes and responses to $S T_{5 \mathrm{~cm}}$ and $W L_{c o l}$ were modeled with a three-level LMM using $S T_{5 \mathrm{~cm}}, W L_{c o l}$, and treatment as interacting fixed effects with a correlated random intercept and slope for each collar nested within site. Annual differences in $\mathrm{CO}_{2}$ and $\mathrm{CH}_{4}$ soil fluxes by treatment were examined using a four-level $L M M$ with $S T_{5 \mathrm{~cm}}, W L_{c o l}$, treatment, and year as interacting fixed-effects terms, with a correlated random intercept and slope for each collar nested within site. A four-level LMM was constructed to compare $\mathrm{CO}_{2}$ fluxes between treatments and study periods using $S T_{5 \mathrm{~cm}}, W L_{c o l}$, treatment, and study period (pre- or posttreatment) as interacting fixed effects, with a correlated 
random intercept and slope for each collar nested within site. Finally, mean untransformed soil gas fluxes were calculated for each site during each sampling event, and Kruskal-Wallis test was used to compare between-treatment means within each year.

Table 1. Model evaluation statistics for soil temperature, $\mathrm{CO}_{2}$ flux, and $\mathrm{CH}_{4}$ flux linear mixed models (LMMs; Figure 2). Residual standard error (RSE) was reported for soil temperature for soil $\mathrm{CO}_{2}$ and $\mathrm{CH}_{4}$ flux LMMs. AIC, Akaike information criterion; PCV, proportion change in variance.

\begin{tabular}{ccccccc}
\hline LMM & Predictors & $r_{c}^{2}$ & $r_{m}^{2}$ & AIC & PCV & RSE \\
\hline Soil Temp. & Null: $\mathrm{x}=A T_{\max }$ & 0.97 & 0.73 & 1763 & - & 0.62 \\
& Full: $\mathrm{x}=A T_{\max } \cdot W L_{m w}$ & 0.98 & 0.73 & 1225 & $0.6 \%$ & 0.39 \\
$\mathrm{CO}_{2}$ Flux & Null: $\mathrm{x}=S T_{5 \mathrm{~cm}}$ & 0.34 & 0.14 & 1564 & - & 2.48 \\
& Full: $\mathrm{x}=S T_{5 \mathrm{~cm}} \cdot W L_{\text {col }}$ & 0.51 & 0.31 & 1489 & $0.2 \%$ & 2.27 \\
$\mathrm{CH}_{4}$ Flux & Null: $\mathrm{x}=S T_{5 \mathrm{~cm}}$ & 0.49 & 0.05 & 621 & - & 0.86 \\
& Full: $\mathrm{x}=S T_{5 \mathrm{~cm}} \cdot W L_{\text {col }}$ & 0.50 & 0.10 & 653 & $0.1 \%$ & 0.85 \\
\hline
\end{tabular}
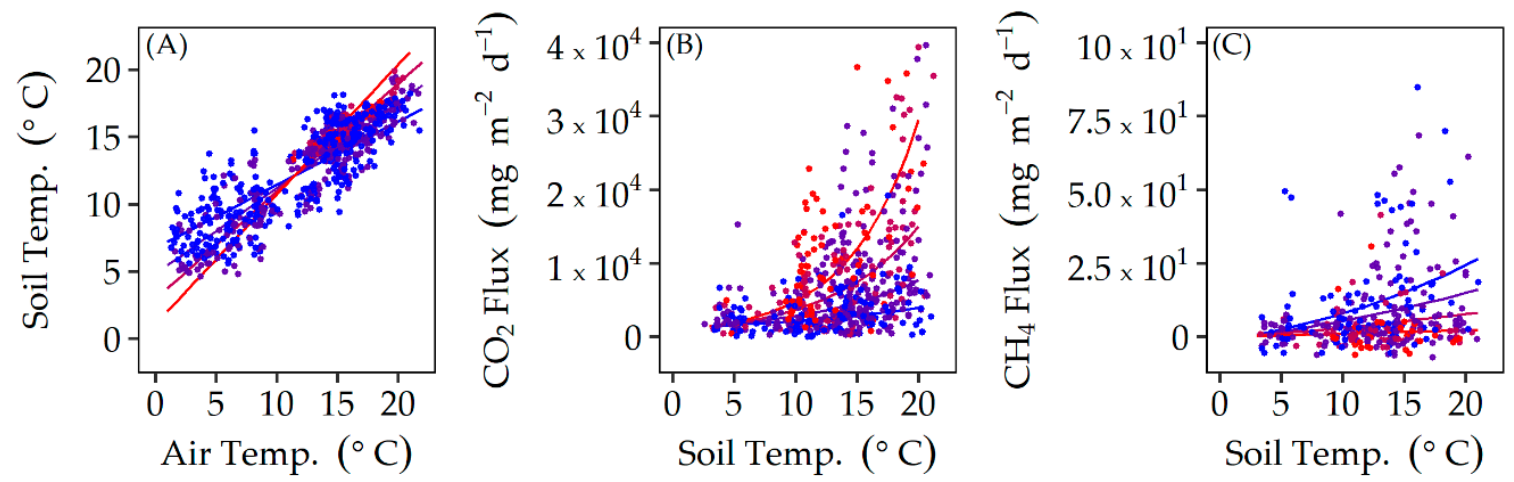

$$
\text { Water Level }(\mathrm{cm}) \rightarrow 10 \rightarrow-10 \rightarrow-30 \rightarrow-50
$$

Figure 2. (A) Responses of daily maximum soil temperatures to daily maximum air temperatures and water levels; (B) Responses of soil $\mathrm{CO}_{2}$ fluxes to soil temperatures and water levels; (C) Responses of soil $\mathrm{CH}_{4}$ fluxes to soil temperatures and water levels. The lines in each panel represent the predicted [57] responses for four water level positions relative to the wetland soil surface. Observations (points) were color coordinated using equidistant binning for the four water level positions, and are used for visual interpretation only.

\section{Results}

\subsection{Regional Climate and Soil Temperature}

Precipitation data for Ironwood, Michigan [44], indicated that the $83 \mathrm{~cm}$ of precipitation received in the ONF during 2012 was below the 30-year average of $89 \mathrm{~cm}$, whereas the $127 \mathrm{~cm}$ and $111 \mathrm{~cm}$ received during 2013 and 2014, respectively, were above the 30-year average. The ONF received approximately $150 \%$ more snow-water equivalent (SWE) precipitation during winter 2012-2013 and 100\% more SWE during winter 2013-2014 compared to winter 2011-2012. In addition, the ONF received approximately 25\% more rain during 2013 and 15\% more rain during 2014 compared to 2012 .

A comparison of model selection criteria indicated that the full LMM $\left(A T_{\max } \cdot W L_{m w}\right)$ for $S T_{\max }$ performed better than the null model ( $A T_{\max }$ only) by improving the relative quality (AIC), increasing the residual proportion change in variance (PCV), and decreasing the residual standard error (RSE). The full LMM explained 0.98 of the conditional variance $\left(r_{c}^{2}\right)$ and 0.73 of the marginal variance $\left(r_{m}^{2}\right)$ (Table 1). The $0.88\left({ }^{\circ} \mathrm{C}^{\circ} \mathrm{C}^{-1}\right)$ slope predicted for the $S T_{\max }$ response to $A T_{\max }$ when $W L_{m w}$ was farthest beneath the soil surface was larger than the $0.39\left({ }^{\circ} \mathrm{C}^{\circ} \mathrm{C}^{-1}\right)$ slope predicted when $W L_{m w}$ was above the soil surface (Figure 2). The mean daily soil temperatures of 13.2 and $13.6^{\circ} \mathrm{C}$ in the girdle and 
ash-cut sites, respectively, were both greater than the $12.7^{\circ} \mathrm{C}$ soil temperature detected in the controls, although these differences were not significant (Table 2).

Table 2. Summary statistics, including degree of freedom (df), standard error (SE), Tukey honest significant difference (Mean Test), and Kruskal-Wallis rank means comparisons (KW Test), for each soil gas $\left(\mathrm{CO}_{2}\right.$ and $\left.\mathrm{CH}_{4}\right)$, study period (pre- and posttreatment), and treatment.

\begin{tabular}{|c|c|c|c|c|c|c|c|c|c|}
\hline Gas & $\begin{array}{l}\text { Study } \\
\text { Period }\end{array}$ & Treatment & $\mathrm{df}$ & $\begin{array}{c}\text { Mean Flux } \\
\left(\mathrm{mg} \mathrm{m}^{-2} \mathrm{~d}^{-1}\right)\end{array}$ & $\begin{array}{c}\mathrm{SE} \\
\left(\mathrm{mg} \mathrm{m}^{-2} \mathrm{~d}^{-1}\right)\end{array}$ & $\begin{array}{l}\text { Mean } \\
\text { Test }\end{array}$ & $\mathbf{n}$ & $\begin{array}{l}\text { Rank } \\
\text { Mean }\end{array}$ & $\begin{array}{l}\text { KW } \\
\text { Test }\end{array}$ \\
\hline \multirow[t]{6}{*}{$\mathrm{CO}_{2}$} & Pre & Control & 18.9 & $3.0 \times 10^{3}$ & 1.26 & a & 10 & 13.5 & a \\
\hline & & Girdle & 16.5 & $4.0 \times 10^{3}$ & 1.25 & a & 10 & 16.5 & a \\
\hline & & Ash-Cut & 30.9 & $5.1 \times 10^{3}$ & 1.32 & a & 10 & 16.5 & a \\
\hline & Post & Control & 6.2 & $3.1 \times 10^{3}$ & 1.18 & a & 24 & 30.8 & a \\
\hline & & Girdle & 7.5 & $5.7 \times 10^{3}$ & 1.19 & $b^{\prime}$ & 24 & 37.4 & $a b$ \\
\hline & & Ash-Cut & 8.7 & $6.7 \times 10^{3}$ & 1.24 & $\mathrm{~b}$ & 24 & 41.3 & $\mathrm{~b}^{\prime}$ \\
\hline \multirow[t]{3}{*}{$\mathrm{CH}_{4}$} & Post & Control & 5.3 & 6.6 & 1.10 & $a b$ & 24 & 33.3 & a \\
\hline & & Girdle & 5.5 & 2.4 & 1.11 & $\mathrm{a}$ & 24 & 26.6 & a \\
\hline & & Ash-Cut & 5.9 & 11.9 & 1.11 & $b^{\prime}$ & 24 & 47.6 & $b$ \\
\hline
\end{tabular}

Significant between-treatment mean differences are indicated by (a) and (b) at $p<0.05$, where $\left(^{\prime}\right)$ indicates detection of marginally significant between-treatment mean differences at $p<0.1$.

\subsection{Soil $\mathrm{CO}_{2}$ and $\mathrm{CH}_{4}$ Fluxes}

As with soil temperature, a comparison of model statistics indicated that the full LMM $\left(S T_{5 \mathrm{~cm}} \cdot W L_{c o l}\right)$ performed better than the null $\mathrm{LMM}\left(S T_{5 \mathrm{~cm}}\right.$ only) for $\mathrm{CO}_{2}$ and $\mathrm{CH}_{4}$, respectively, by increasing the $r_{c}^{2}$ and $r_{m}^{2}$, increasing the PCV, and decreasing the RSE (Table 1). The predicted slope of the $\mathrm{CO}_{2}$ flux response to soil temperature was $0.18\left(\mathrm{mg} \mathrm{m}^{-2}\right.$ day $\left.{ }^{-1}{ }^{\circ} \mathrm{C}^{-1}\right)$ when $W L_{\text {col }}$ was farthest beneath the soil surface, and this value was larger than the $0.06\left(\mathrm{mg} \mathrm{m}^{-2}\right.$ day $\left.^{-1}{ }^{\circ} \mathrm{C}^{-1}\right)$ response slope predicted when $W L_{c o l}$ was above the soil surface (Figure 2) [57]. Conversely, the predicted slope of the $\mathrm{CH}_{4}$ flux response to soil temperature was $0.05\left(\mathrm{mg} \mathrm{m}^{-2}\right.$ day $\left.^{-1}{ }^{\circ} \mathrm{C}^{-1}\right)$ when $W L_{c o l}$ was above the soil surface, and this value was larger than the $0.006\left(\mathrm{mg} \mathrm{m}^{-2}\right.$ day $\left.^{-1}{ }^{\circ} \mathrm{C}^{-1}\right)$ response slope predicted when $W L_{c o l}$ was farthest below the soil surface (Figure 2).

Soil temperature $\left(S T_{5 \mathrm{~cm}}\right)$ and water level $\left(W L_{c o l}\right)$ were used to predict soil $\mathrm{CO}_{2}$ and $\mathrm{CH}_{4}$ fluxes for each treatment during the posttreatment study period (Figure 3). The $\mathrm{CO}_{2}$ flux LMM had a $0.52 r_{c}^{2}$ and $0.35 r_{m}^{2}$ and a residual standard error of $2.1 \mathrm{mg} \mathrm{m}^{-2}$ day ${ }^{-1}$, whereas the $\mathrm{CH}_{4}$ flux LMM had a $0.37 r_{c}^{2}$ and $0.24 r_{m}^{2}$ and a residual standard error of $0.9 \mathrm{mg} \mathrm{m}^{-2}$ day $^{-1}$. Due to the limited number of $\mathrm{CO}_{2}$ flux observations collected when soil temperatures were less than $10^{\circ} \mathrm{C}$ during the pretreatment study period and the absence of pretreatment $\mathrm{CH}_{4}$ flux observations, the pretreatment response slope estimates were either not reliable or nonexistent and therefore were excluded from the three-level LMM. The girdle, ash-cut, and control response slopes for soil $\mathrm{CO}_{2}$ flux $\left(0.10,0.08\right.$, and $0.10 \mathrm{mg} \mathrm{m}^{-2}$ day $\left.^{-1}{ }^{\circ} \mathrm{C}^{-1}\right)$ and soil $\mathrm{CH}_{4}$ flux $\left(0.02,0.04\right.$, and $0.06 \mathrm{mg} \mathrm{m}^{-2}$ day $\left.^{-1}{ }^{\circ} \mathrm{C}^{-1}\right)$ were not significantly different from one another during the posttreatment study period. The mean $\mathrm{CO}_{2}$ flux detected in ash-cut sites was marginally significantly higher than the controls $(p=0.094)$, and the mean $\mathrm{CH}_{4}$ fluxes detected in the girdle and ash-cut sites were not significantly different $(p>0.1)$ than the control sites during the posttreatment study period (Figure 3). 


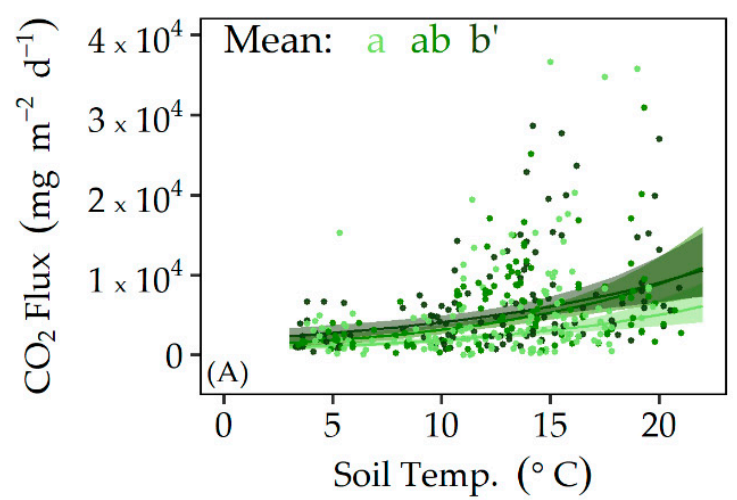

Treatment $\rightarrow$ Control

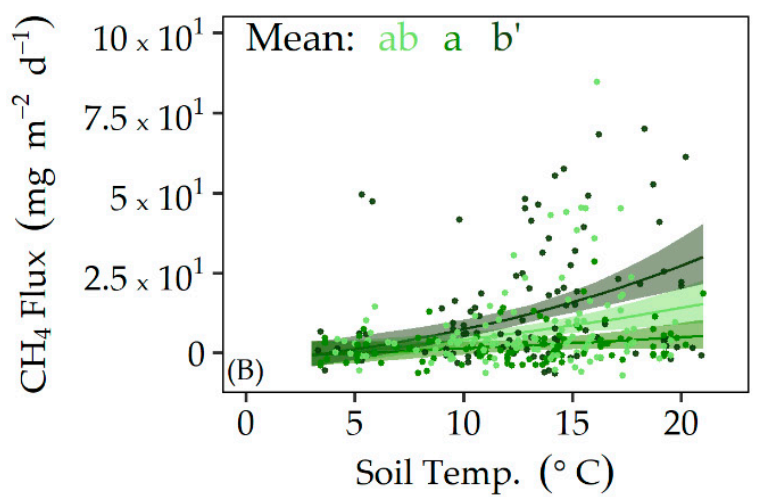

Girdle $\rightarrow$ Ash-Cut

Figure 3. (A) Predicted soil $\mathrm{CO}_{2}$ flux response to soil temperature and water level $\left(W L_{c o l}\right)$ for each treatment, with shaded 95\% confidence intervals [57]; (B) Predicted soil $\mathrm{CH}_{4}$ flux response to soil temperature and water level $\left(W L_{c o l}\right)$ for each treatment, with shaded $95 \%$ confidence intervals. $W L_{c o l}$ was embedded, using a correlated random intercept and slope, within each LMM as an interacting fixed effect. Significant differences between treatment means are indicated by (a) and (b) at $p<0.05$, where $\left({ }^{\prime}\right)$ indicates detection of marginally significant between-treatment means differences at $p<0.1$.

There were no significant differences in mean soil $\mathrm{CO}_{2}$ flux detected among treatments during 2012 (pretreatment), whereas the $6599 \mathrm{mg} \mathrm{m}^{-2}$ day ${ }^{-1}$ ash-cut mean soil $\mathrm{CO}_{2}$ flux was marginally significantly higher $(p=0.076)$ than the $3193 \mathrm{mg} \mathrm{m}^{-2}$ day $^{-1}$ control mean soil $\mathrm{CO}_{2}$ flux during 2013, and the 6722 and 6835 mean soil $\mathrm{CO}_{2}$ fluxes in the girdle $(p=0.042)$ and ash-cut $(p=0.042)$, respectively, were significantly higher than the $2979 \mathrm{mg} \mathrm{m}^{-2}$ day $^{-1}$ control mean soil $\mathrm{CO}_{2}$ flux during 2014 (Figure 4). Neither the girdle nor the ash-cut soil $\mathrm{CH}_{4}$ fluxes were significantly different than the control during 2013 and 2014 (Figure 4). When the entire pre- and posttreatment periods were considered, the 5625 and $6545 \mathrm{mg} \mathrm{m}^{-2}$ day $^{-1}$ mean soil $\mathrm{CO}_{2}$ fluxes detected in the girdle $(p=0.096)$ and ash-cut sites $(p=0.046)$, respectively, were significantly higher than the $3038 \mathrm{mg} \mathrm{m}^{-2}$ day $^{-1}$ detected in the control sites during the posttreatment study period (Table 2). The nonparametric Kruskal-Wallis test shows that higher $\mathrm{CO}_{2}$ fluxes occurred more frequently in the ash-cut than the controls $(p=0.085)$ (Table 2). The $11.9 \mathrm{mg}$ $\mathrm{m}^{-2}$ day $^{-1}$ ash-cut mean soil $\mathrm{CH}_{4}$ flux was almost twice as high as the $6.6 \mathrm{mg} \mathrm{m}^{-2}$ day $^{-1}$ control mean soil $\mathrm{CH}_{4}$ flux, and marginally significantly $(p=0.079)$ higher than the $2.4 \mathrm{mg} \mathrm{m}^{-2}$ day $^{-1}$ girdle mean soil $\mathrm{CH}_{4}$ flux during the posttreatment study period (Table 2). While the mean $\mathrm{CH}_{4}$ fluxes detected in girdle and ash-cut sites were similar to controls during the posttreatment period, the nonparametric Kruskal-Wallis test shows that higher $\mathrm{CH}_{4}$ fluxes occurred more frequently in the ash-cut sites than the controls $(p=0.026)$ (Table 2). Within-treatment soil $\mathrm{CO}_{2}$ flux comparisons were not considered due to the limited number of flux observations collected when soil temperatures were less than $10{ }^{\circ} \mathrm{C}$ during the pretreatment study period, and no pretreatment $\mathrm{CH}_{4}$ flux data were available. 

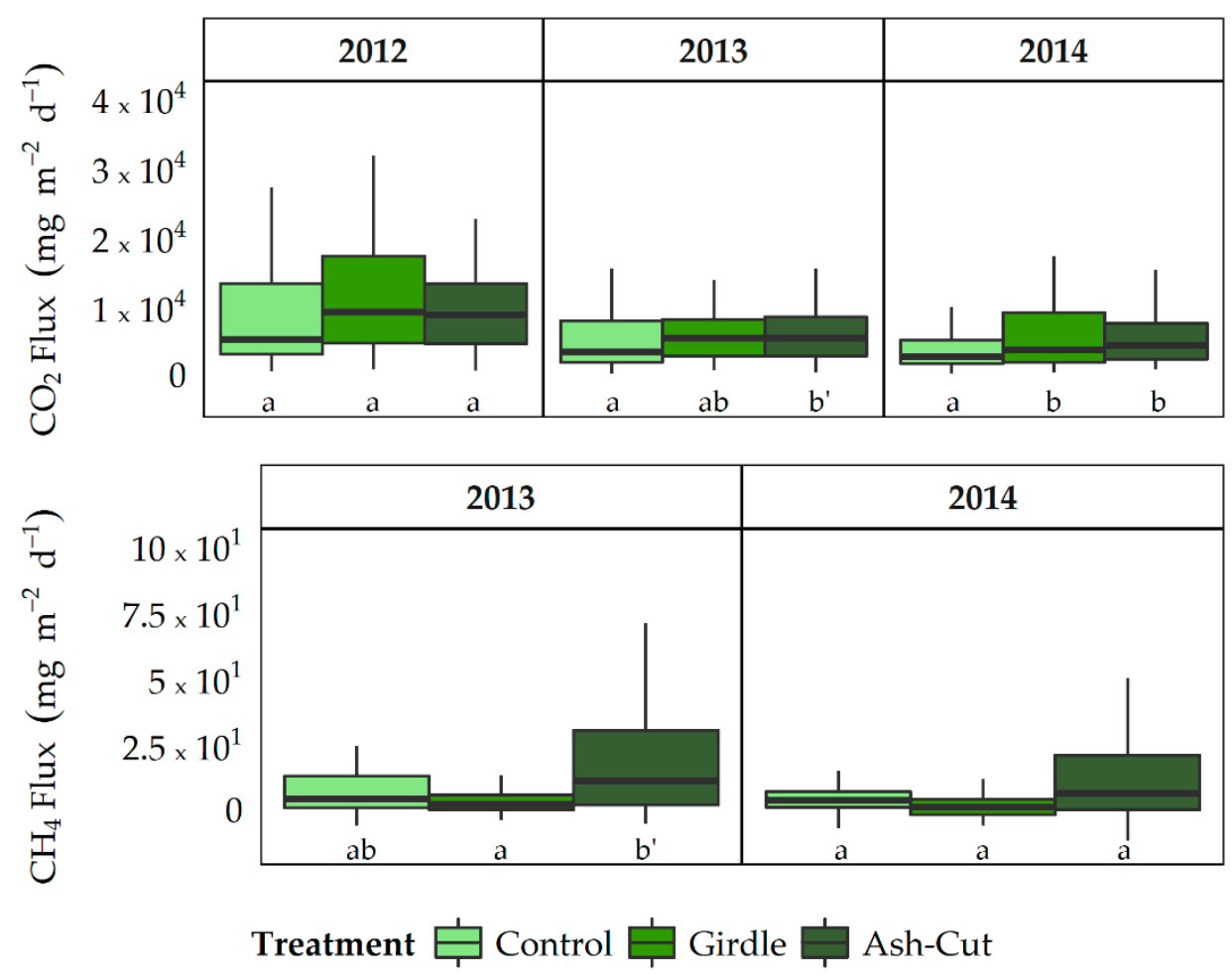

Figure 4. (A) Soil $\mathrm{CO}_{2}$ flux for each treatment during 2012, 2013, and 2014; (B) Soil $\mathrm{CH}_{4}$ flux for each treatment during 2013 and 2014. Significant between-treatment differences in mean flux at $p>0.05$ are indicated by (a) and (b), where $\left(^{\prime}\right)$ indicates detection of marginally significant between-treatment mean differences at $p<0.1$. Boxplot lines represent median, $25 \%$, and $75 \%$ quantiles, while whiskers represent quantiles \pm 1.5 - interquantile range, respectively [58].

\section{Discussion}

\subsection{Soil Temperature and Water Level}

Wetland water level $\left(W L_{m w}\right)$ significantly altered the response of soil temperature $\left(S T_{\max }\right)$ to air temperature $\left(A T_{\max } ;\right.$ Figure 2). When $W L_{m w}$ was lower and the soil presumably drier, $S T_{\max }$ more closely paralleled $A T_{\max }$. In contrast, when $W L_{m w}$ was higher (near or above surface), $S T_{\max }$ was less correlated to $A T_{\max }$. The combined influence of the higher specific heat capacity of water and the consistent groundwater discharge into black ash wetlands [17] likely decreased the sensitivity of $S T_{\max }$ to $A T_{\max }$ when soils were saturated. Furthermore, soil temperature response to treatment was likely mitigated by the consistent influx of groundwater because of the expected increase in magnitude of latent heat exchange and reduction in magnitude of sensible heat exchange between soil and atmosphere [59].

The wetter conditions (Table 2) and higher wetland water levels during the posttreatment period [17] may have buffered the magnitude of $S T_{\max }$ response to disturbance. Because of the wetter-than-average posttreatment water years and the resultant elevated water tables, the average soil temperatures in girdle and ash-cut sites were not significantly greater than the controls, despite the presumed increase in canopy openness and insolation. We theorized that the increased amount of insolation likely received by soils in the disturbed study sites would have a greater influence on the response of $S T_{\max }$ to $A T_{\max }$ during drier periods. It is likely that average $S T_{\max }$ differences would have been larger during the posttreatment study period under drier conditions. 


\subsection{Responses of Soil $\mathrm{CO}_{2}$ and $\mathrm{CH}_{4}$ Fluxes to Disturbance}

The water level position relative to the wetland soil surface $\left(W L_{c o l}\right)$ regulated the response of soil $\mathrm{CO}_{2}$ and $\mathrm{CH}_{4}$ fluxes to soil temperature $\left(\mathrm{ST}_{5 \mathrm{~cm}}\right.$; Figure 2), and co-varied soil $\mathrm{CO}_{2}$ and $\mathrm{CH}_{4}$ flux responses to $S T_{5 \mathrm{~cm}}$ and $W L_{c o l}$ have been observed in numerous wetland types [15,19,60]. Soil $\mathrm{CO}_{2}$ fluxes tended to be higher and increase more rapidly in response to increased temperature when $W L_{c o l}$ was below the wetland soil surface, whereas soil $\mathrm{CH}_{4}$ fluxes tended to be higher and increase more rapidly in response to increased temperature when $W L_{c o l}$ was at or above the wetland soil surface. The magnitude of observed soil $\mathrm{CO}_{2}$ and $\mathrm{CH}_{4}$ fluxes from depressional black ash wetlands was similar to fluxes observed in wetlands under field and laboratory conditions [15,61-63].

Given that both the magnitude of soil $\mathrm{CO}_{2}$ and $\mathrm{CH}_{4}$ fluxes and the correlation of $S T_{\max }$ to $A T_{\max }$ were controlled by wetland water levels, it is likely that interannual climatic conditions also affect the relative magnitude of mean annual soil $\mathrm{CO}_{2}$ and $\mathrm{CH}_{4}$ fluxes. Specifically, mean annual soil $\mathrm{CO}_{2}$ fluxes may be higher during drier periods and lower during wetter periods. Conversely, soil $\mathrm{CH}_{4}$ fluxes would be expected to be higher during wetter periods and lower during drier periods. Therefore, it is possible that the soil $\mathrm{CO}_{2}$ flux response to disturbance was buffered and the soil $\mathrm{CH}_{4}$ flux response was enhanced because of the wetter-than-average conditions during the posttreatment study period [17]. Black ash wetland water levels tended to be higher during the two wetter water years [17], and soil temperature tended to be less responsive to air temperature when water levels were higher (Figure 2). Moreover, wetland soil $\mathrm{CO}_{2}$ fluxes are typically lower when water tables are above the surface compared to fluxes measured during lower water table positions $[19,62]$ Therefore, soil $\mathrm{CO}_{2}$ fluxes from disturbed sites may have been higher and possibly more dissimilar than control sites if drier climatic conditions had occurred during the two posttreatment monitoring years.

The magnitude of soil $\mathrm{CO}_{2}$ fluxes was significantly higher in disturbed sites, and high soil $\mathrm{CH}_{4}$ fluxes occurred more frequently in the ash-cut than the control during the posttreatment study period (Figures 3 and 4; Table 2). As evidenced by the similarity among slopes, the sensitivity of soil $\mathrm{CO}_{2}$ fluxes to environmental variables $\left(S T_{5 \mathrm{~cm}}\right.$ and $\left.W L_{c o l}\right)$ did not change following disturbance (Figure 3). Therefore, the higher soil $\mathrm{CO}_{2}$ fluxes from disturbed sites were not caused by an altered sensitivity to environmental variables. Similarly, soil $\mathrm{CH}_{4}$ response slopes for the three treatments were not significantly different from one another during the posttreatment study period (Figure 3), and the significantly more frequent occurrence of high $\mathrm{CH}_{4}$ fluxes in ash-cut sites may not have been caused by an altered sensitivity to environmental variables.

It is possible that the increased rate of heterotrophic respiration from disturbed soils stemmed from an alteration in the organic chemical composition of peatland soil [64]. Carbon mineralization rates were positively correlated with labile carbon compounds and negatively correlated with recalcitrant carbon compounds in a northern Minnesota peatland [65]. Increased rates of $\mathrm{CH}_{4}$ production were detected following the addition of glucose to lignin-rich peat in northern North American peatlands matter [66], and $\mathrm{CO}_{2}$ and $\mathrm{CH}_{4}$ production was significantly affected by $\mathrm{pH}$ and $\mathrm{C}: \mathrm{N}$ ratios in Dutch peat grasslands [67]. Fine root respiration may also account for a substantial proportion of soil $\mathrm{CO}_{2}$ fluxes, and increased soil $\mathrm{CO}_{2}$ fluxes have been attributed to turnover and decomposition of fine roots [68-70]. Black ash trees have a shallow, fibrous root system [71], and the majority of this fine root system was likely available for decomposition following disturbance. Unlike the rapid infilling from co-occurring tree species that occurred following EAB infestation in green ash (Fraxinus pennsylvanica Marsh.) stands in northwest Ohio [72], neither overstory or understory stems of co-occurring tree species within these black ash wetland study sites responded positively following treatment [42]. Therefore, the increased magnitude of $\mathrm{CO}_{2}$ fluxes (Figure 4) from disturbed black ash wetland soils may be at least partially attributed to the transient large influx of decomposable fine roots and an associated response in microbial activity and biomass [63,73], and not likely the result of increased autotrophic respiration from the release of co-occurring tree species. Inversely, the loss of autotrophic root respiration from mature individuals may lead to a decrease in soil $\mathrm{CO}_{2}$ flux following disturbance [74,75]. A lack of 
response of inorganic soil nitrogen availability following treatment in these sites during this study period [76] supports the explanation that increased microbial activity drove the observed $\mathrm{CO}_{2}$ response.

The study sites were consistently connected to mineral-rich groundwater during the study period [17], and this connection likely influenced carbon mineralization dynamics within depressional black ash wetland soils. The relative standard error of soil $\mathrm{CH}_{4}$ fluxes $(18.0 \%)$ was considerably larger than the relative standard error of soil $\mathrm{CO}_{2}$ fluxes $(<0.1 \%$; Table 2). Because the highest rates of methane oxidation are expected near oxic/anoxic interfaces [28], the large variation of soil $\mathrm{CH}_{4}$ fluxes that occurred when wetlands were saturated and/or inundated (Figure 3) was not likely caused by increased rates of methanotrophy within the peat profile. This further suggests that methanogenesis may have been constrained by the availability of electron acceptors [77], inhibited by chemical compounds [28] or low $\mathrm{pH}$ [78], or transported to the atmosphere through vegetation with arenchyma $[79,80]$.

When compared to control sites, and because of the warmer and wetter conditions observed in the disturbed sites after treatment, we expected to observe higher posttreatment mean soil $\mathrm{CH}_{4}$ fluxes in ash-cut and girdle sites. However, the persistent connection with mineral-rich groundwater during the wetter posttreatment study period may, in fact, have buffered the relative magnitude of $\mathrm{CH}_{4}$ flux response to disturbance by inhibiting methanogenesis. Specifically, it is likely that study sites were consistently being replenished with more efficient electron-accepting redox species such as $\mathrm{Fe}^{2+}, \mathrm{Mn}^{4+}$, or $\mathrm{SO}_{4}^{2-}$ during the wetter posttreatment period, which effectively inhibited methanogenesis. It is also possible that methane production within the soil increased following disturbance, but increased $\mathrm{CH}_{4}$ fluxes were not detected from the soil surface due to plant-mediated transport.

The large increase of herbaceous cover following disturbance in these sites may have limited natural woody regeneration recruitment to larger seedling size classes or saplings [42], and canopy removal has been shown to convert black ash-dominated wetlands to herbaceous or scrub-shrub-dominated wetlands [81]. As a result, canopy replacement through natural regeneration may take several decades [82], where planting mitigation efforts will influence the tree species composition, likely decrease the duration of canopy recovery, and help maintain ecosystem function following disturbance [83-85]. Though the hydrogeomorphic setting is distinctly different from the black ash wetlands considered here, these findings may have important implications for potential effects in other ash-dominated wetlands such as those dominated by green and pumpkin ash (Fraxinus profunda Bush). The contribution of herbaceous vegetation to soil respiration following disturbance may be substantial [86], and the contribution of the herbaceous community to autotrophic soil respiration may have increased, given the increased amount of herbaceous cover detected in these sites post treatment [42]. In addition, the increased magnitude of heterotrophic respiration associated with the elevated soil temperatures and transient large influx of decomposable fine roots likely contributed to the significantly higher girdle and ash-cut mean soil $\mathrm{CO}_{2}$ fluxes during the posttreatment period when compared to controls. Warmer and wetter conditions are expected in the upper Great Lakes region under elevated atmospheric $\mathrm{CO}_{2}$ conditions, which may also affect soil $\mathrm{CH}_{4}$ fluxes in EAB-affected wetlands [87]. Therefore, it is likely that successful planting mitigation efforts will effectively decrease the duration of $\mathrm{EAB}$ infestation-induced increases of soil $\mathrm{CO}_{2}$ fluxes and buffer the losses of soil $\mathrm{C}$ storage within depressional black ash wetlands.

\section{Conclusions}

Control, girdle, and ash-cut treatments were applied to three sites and used to simulate an EAB disturbance. Water level, soil temperature, and soil $\mathrm{CO}_{2}$ and $\mathrm{CH}_{4}$ fluxes were monitored during preand posttreatment study periods. Mean soil temperatures were higher in girdle and ash-cut sites compared to the controls. The relative water table position influenced the degree of soil temperature sensitivity to air temperature, where soil temperature more closely paralleled air temperature when water levels were below the wetland soil surface. Consequently, the wetter-than-average posttreatment climatic conditions [17] likely inhibited the magnitude of soil temperature response to disturbance 
where average or drier-than-average climatic conditions may have yielded even larger differences between treated and untreated sites.

Soil $\mathrm{CO}_{2}$ fluxes were significantly higher and higher soil $\mathrm{CH}_{4}$ fluxes occurred more frequently in disturbed sites, but mean soil $\mathrm{CH}_{4}$ fluxes were similar in disturbed and undisturbed sites. Soil temperature and wetland water levels controlled soil $\mathrm{CO}_{2}$ and $\mathrm{CH}_{4}$ fluxes, where warmer and drier conditions yielded higher soil $\mathrm{CO}_{2}$ fluxes, and warmer and wetter conditions yielded higher soil $\mathrm{CH}_{4}$ fluxes. The relationship between soil $\mathrm{CO}_{2}$ and $\mathrm{CH}_{4}$ fluxes and soil temperature and water level was not influenced by a simulated $\mathrm{EAB}$ disturbance. The combination of higher mean soil temperatures, increased herbaceous cover, and the transient large influx of decomposable fine roots following canopy suppression may have contributed to the higher soil $\mathrm{CO}_{2}$ fluxes detected in disturbed sites. Conversely, the consistent connection with mineral-rich groundwater flow likely constrained methanogenesis, and consequently reduced the relative magnitude of soil $\mathrm{CH}_{4}$ flux response to a simulated EAB disturbance.

Black ash wetland soil carbon mineralization processes were sensitive, but also showed resilience to EAB-induced impacts. Both $\mathrm{CO}_{2}$ and $\mathrm{CH}_{4}$ fluxes were regulated by soil temperature and water level position. The consistent connection with groundwater flow systems and wetter-than-average weather conditions during the posttreatment period likely buffered the relative magnitude of soil $\mathrm{CH}_{4}$ response to disturbance.

Author Contributions: M.V.G., J.S., J.D., R.K., and T.P. conceived and designed the experiments; M.V.G., J.S., N.B., and J.D. performed the experiments; M.V.G., J.S., and N.B. analyzed the data; and all authors contributed to writing the paper.

Acknowledgments: We appreciate the support of the US Forest Service, in particular Mark Fedora, and the rest of the Ottawa National Forest. Funding for this project was provided by the USDA, the US-EPA Great Lakes Restoration Initiative (DW-12-92429101-0), Michigan Tech's Center for Water and Society, and Michigan Tech's Ecosystem Science Center. Special thanks to Stephen Sebestyen, Alex Mayer, Robert Froese, Nicholas Schreiner, Jarrod Nelson, Leah Harrison, Erica Jones, Jon Bontrager, Dan Hutchinson, John Hrjiblan, Lynette Potvin, and Timothy Veverica for their technical and logistical support.

Conflicts of Interest: The authors declare no conflict of interest.

\section{References}

1. McLaughlin, J.W.; Gale, M.R.; Jurgensen, M.F.; Trettin, C.C. Soil organic matter and nitrogen cycling in response to harvesting, mechanical site preparation, and fertilization in a wetland with a mineral substrate. For. Ecol. Manag. 2000, 129, 7-23. [CrossRef]

2. Sun, G.; McNulty, S.G.; Shepard, J.P.; Amatya, D.M.; Riekerk, H.; Comerford, N.B.; Skaggs, W.; Swift, L. Effects of timber management on the hydrology of wetland forests in the southern united states. For. Ecol. Manag. 2001, 143, 227-236. [CrossRef]

3. MacFarlane, D.W.; Meyer, S.P. Characteristics and distribution of potential ash tree hosts for emerald ash borer. For. Ecol. Manag. 2005, 213, 15-24. [CrossRef]

4. Kashian, D.M.; Witter, J.A. Assessing the potential for ash canopy tree replacement via current regeneration following emerald ash borer-caused mortality on southeastern Michigan landscapes. For. Ecol. Manag. 2011, 261, 480-488. [CrossRef]

5. Flower, C.E.; Knight, K.S.; Gonzalez-Meler, M.A. Impacts of the emerald ash borer (Agrilus planipennis fairmaire) induced ash (Fraxinus spp.) mortality on forest carbon cycling and successional dynamics in the eastern united states. Biol. Invasions 2013, 15, 931-944. [CrossRef]

6. Sydnor, T.D.; Bumgardner, M.; Todd, A. The potential economic impacts of emerald ash borer (Agrilus planipennis) on Ohio, US, Communities. Arboricult. Urban For. 2007, 33, 48-54.

7. Kovacs, K.F.; Haight, R.G.; McCullough, D.G.; Mercader, R.J.; Siegert, N.W.; Liebhold, A.M. Cost of potential emerald ash borer damage in U.S. Communities, 2009-2019. Ecol. Econ. 2010, 69, 569-578. [CrossRef]

8. Gandhi, K.K.; Herms, D. Direct and indirect effects of alien insect herbivores on ecological processes and interactions in forests of eastern north America. Biol. Invasions 2010, 12, 389-405. [CrossRef]

9. Lovett, G.M.; Canham, C.D.; Arthur, M.A.; Weathers, K.C.; Fitzhugh, R.D. Forest ecosystem responses to exotic pests and pathogens in eastern north America. BioScience 2006, 56, 395-405. [CrossRef] 
10. Kimble, J.M. The Potential of U.S. Forest Soils to Sequester Carbon and Mitigate the Greenhouse Effect; CRC Press: Boca Raton, FL, USA, 2003; p. 429.

11. Freeman, C.; Ostle, N.; Kang, H. An enzymic 'latch' on a global carbon store-A shortage of oxygen locks up carbon in peatlands by restraining a single enzyme. Nature 2001, 409, 149. [CrossRef] [PubMed]

12. Gorham, E. Northern peatlands: Role in the carbon cycle and probable responses to climatic warming. Ecol. Appl. 1991, 1, 182-195. [CrossRef] [PubMed]

13. Hogberg, P.; Nordgren, A.; Buchmann, N.; Taylor, A.F.S.; Ekblad, A.; Hogberg, M.N.; Nyberg, G.; Ottosson-Lofvenius, M.; Read, D.J. Large-scale forest girdling shows that current photosynthesis drives soil respiration. Nature 2001, 411, 789-792. [CrossRef] [PubMed]

14. Zerva, A.; Mencuccini, M. Short-term effects of clearfelling on soil $\mathrm{CO}_{2}, \mathrm{CH}_{4}$, and $\mathrm{N}_{2} \mathrm{O}$ fluxes in a sitka spruce plantation. Soil Biol. Biochem. 2005, 37, 2025-2036. [CrossRef]

15. Moore, T.R.; Dalva, M. The influence of temperature and water-table position on carbon-dioxide and methane emissions from laboratory columns of peatland soils. J. Soil Sci. 1993, 44, 651-664. [CrossRef]

16. Macdonald, J.A.; Fowler, D.; Hargreaves, K.J.; Skiba, U.; Leith, I.D.; Murray, M.B. Methane emission rates from a northern wetland; response to temperature, water table and transport. Atmos. Environ. 1998, 32, 3219-3227. [CrossRef]

17. Van Grinsven, M.J.; Shannon, J.P.; Davis, J.C.; Bolton, N.W.; Wagenbrenner, J.W.; Kolka, R.K.; Grant Pypker, T. Source water contributions and hydrologic responses to simulated emerald ash borer infestations in depressional black ash wetlands. Ecohydrology 2017, 10. [CrossRef]

18. Slesak, R.A.; Lenhart, C.F.; Brooks, K.N.; D’Amato, A.W.; Palik, B.J. Water table response to harvesting and simulated emerald ash borer mortality in black ash wetlands in Minnesota, USA. Can. J. For. Res. 2014, 44, 961-968. [CrossRef]

19. Blodau, C. Carbon cycling in peatlands-A review of processes and controls. Environ. Rev. 2002, 10, 111-134. [CrossRef]

20. Nancy, D.; Narasinha, S.; Peter, W.; Shashi, V.; Elon, V.; Eville, G.; Patrick, C.; Robert, H.; Cheryl, K.; Joseph, Y.; et al. Carbon emissions from peatlands. In Peatland Biogeochemistry and Watershed Hydrology at the Marcell Experimental Forest; CRC Press: Boca Raton, FL, USA, 2011; pp. 297-347.

21. McFee, W.W.; Kelly, J.M. Soil carbon in northern forested wetlands: Impacts of silvicultural practices. Carbon 1995, 1, 437-461.

22. Trettin, C.C.; Jurgensen, M.F.; Grigal, D.F.; Gale, M.R.; Jeglum, J.R. Northern Forested Wetlands Ecology and Management; CRC Press: Boca Raton, FL, USA, 1996.

23. Eswaran, H.; Van Den Berg, E.; Reich, P. Organic carbon in soils of the world. Soil Sci. Soc. Am. J. 1993, 57, 192-194. [CrossRef]

24. Bridgham, S.; Megonigal, J.P.; Keller, J.; Bliss, N.; Trettin, C. The carbon balance of north American wetlands. Wetlands 2006, 26, 889-916. [CrossRef]

25. Freeman, C.; Kim, S.Y.; Lee, S.H.; Kang, H. Effects of elevated atmospheric $\mathrm{CO}_{2}$ concentrations on soil microorganisms. J. Microbiol. 2004, 42, 267-277. [PubMed]

26. Blodau, C.; Basiliko, N.; Moore, T.R. Carbon turnover in peatland mesocosms exposed to different water table levels. Biogeochemistry 2004, 67, 331-351. [CrossRef]

27. Dalva, M.; Moore, T.R.; Arp, P.; Clair, T.A. Methane and soil and plant community respiration from wetlands, Kejimkujik National Park, Nova Scotia: Measurements, predictions, and climatic change. J. Geophys. Res. Atmos. 2001, 106, 2955-2962. [CrossRef]

28. Segers, R. Methane production and methane consumption: A review of processes underlying wetland methane fluxes. Biogeochemistry 1998, 41, 23-51. [CrossRef]

29. Aller, R.C. Bioturbation and remineralization of sedimentary organic-matter-Effects of redox oscillation. Chem. Geol. 1994, 114, 331-345. [CrossRef]

30. van Hulzen, J.B.; Segers, R.; van Bodegom, P.M.; Leffelaar, P.A. Temperature effects on soil methane production: An explanation for observed variability. Soil Biol. Biochem. 1999, 31, 1919-1929. [CrossRef]

31. Fissore, C.; Giardina, C.P.; Kolka, R.K.; Trettin, C.C. Soil organic carbon quality in forested mineral wetlands at different mean annual temperature. Soil Biol. Biochem. 2009, 41, 458-466. [CrossRef]

32. Hagerty, S.B.; Van Groenigen, K.J.; Allison, S.D.; Hungate, B.A.; Schwartz, E.; Koch, G.W.; Kolka, R.K.; Dijkstra, P. Accelerated microbial turnover but constant growth efficiency with warming in soil. Nat. Clim. Chang. 2014, 4, 903-906. [CrossRef] 
33. Daulat, W.E.; Clymo, R.S. Effects of temperature and watertable on the efflux of methane from peatland surface cores. Atmos. Environ. 1998, 32, 3207-3218. [CrossRef]

34. Kettunen, A.; Kaitala, V.; Lehtinen, A.; Lohila, A.; Alm, J.; Silvola, J.; Martikainen, P.J. Methane production and oxidation potentials in relation to water table fluctuations in two boreal mires. Soil Biol. Biochem. 1999, 31, 1741-1749. [CrossRef]

35. Peters, V.; Conrad, R. Sequential reduction processes and initiation of $\mathrm{CH}_{4}$ production upon flooding of oxic upland soils. Soil Biol. Biochem. 1996, 28, 371-382. [CrossRef]

36. Moore, T.R.; Heyes, A.; Roulet, N.T. Methane emissions from wetlands, southern hudson-bay lowland. J. Geophys. Res. Atmos. 1994, 99, 1455-1467. [CrossRef]

37. Amaral, J.A.; Knowles, R. Methane metabolism in a temperate swamp. Appl. Environ. Microbiol. 1994, 60, 3945-3951. [PubMed]

38. Shannon, R.D.; White, J.R. A three-year study of controls on methane emissions from two Michigan peatlands. Biogeochemistry 1994, 27, 35-60. [CrossRef]

39. Ballantyne, D.; Hribljan, J.; Pypker, T.; Chimner, R. Long-term water table manipulations alter peatland gaseous carbon fluxes in northern Michigan. Wetl. Ecol. Manag. 2014, 22, 35-47. [CrossRef]

40. Johnson, C.P.; Pypker, T.G.; Hribljan, J.A.; Chimner, R.A. Open top chambers and infrared lamps: A comparison of heating efficacy and $\mathrm{CO}_{2} / \mathrm{CH}_{4}$ dynamics in a northern Michigan peatland. Ecosystems 2013, 16, 736-748. [CrossRef]

41. Prasad, A.M.; Iverson, L.R. Little's Range and FIA Importance Value Database for 135 Eastern US Tree Species; Northeastern Research Station: Delaware, OH, USA, 2003.

42. Davis, J.C.; Shannon, J.P.; Bolton, N.W.; Kolka, R.K.; Pypker, T. Vegetation responses to simulated emerald ash borer infestation in Fraxinus nigra dominated wetlands of Upper Michigan, USA. Can. J. For. Res. 2017, 47, 319-330. [CrossRef]

43. Soil Survey Staff. Web Soil Survey. Natural Resources Conservation Service, United States Department of Agriculture. Available online: http:/ / websoilsurvey.Nrcs.Usda.Gov / (accessed on 14 November 2014).

44. NOAA-NCEI. National Oceanic and Atomospheric Administration. National Centers for Environmental Information: Asheville, NC, USA. Available online: https:/ / www.ncei.noaa.gov / (accessed on 15 November 2017).

45. McCullough, D.G.; Schneeberger, N.F.; Katovich, S.A.; Siegert, N.W. Pest Alert: Emerald Ash Borer. USDA For. Serv., Northeastern Area, State \& Private Forestry: Newtown Square, PA, USA, 2015. NA-PR-02-04. Available online: http://www.na.fs.fed.us/spfo/pubs/pest_al/eab/eab.pdf (accessed on 5 December 2017).

46. Tuittila, E.-S.; Komulainen, V.-M.; Vasander, H.; Nykänen, H.; Martikainen, P.J.; Laine, J. Methane dynamics of a restored cut-away peatland. Glob. Chang. Biol. 2000, 6, 569-581. [CrossRef]

47. Carroll, P.; Crill, P. Carbon balance of a temperate poor fen. Glob. Biogeochem. Cycles 1997, 11, 349-356. [CrossRef]

48. R Core Team. R: A Language and Environment for Statistical Computing [Computer Software]; R: Foundation for Statistical Computing: Vienna, Austria, 2016.

49. Bates, D.; Mächler, M.; Bolker, B.; Walker, S. Fitting linear mixed-effects models using LME4. J. Stat. Softw. 2015, 67, 1-48. [CrossRef]

50. Skoog, D.A.; Holler, J.; Crouch, S.R. Liquid chromatography. In Principles of Instrumental Analysis, 6th ed.; Thomson Cengage Learning: Boston, MA, USA, 2006; pp. 816-855.

51. Hewett, P.; Ganser, G.H. A comparison of several methods for analyzing censored data. Ann. Occup. Hyg. 2007, 51, 611-632. [PubMed]

52. Millard, S.P. Envstats, an R Package for Environmental Statistics; Springer Science \& Business Media: Berlin, Germany, 2013.

53. Nakagawa, S.; Schielzeth, H. A general and simple method for obtaining R2 from generalized linear mixed-effects models. Methods Ecol. Evol. 2013, 4, 133-142. [CrossRef]

54. Lenth, R.V. Lsmeans: Least-Squares Means. R Package Version 2013, Volume 2. Available online: https: / / www.jstatsoft.org/article/view/v069i01/0 (accessed on 18 October 2016).

55. Halekoh, U.; Højsgaard, S.; Højsgaard, M.S.; Matrix, I. Package 'pbkrtest'. 2014. Available online: https: / / cran.r-project.org/web/packages/pbkrtest/index.html (accessed on 23 September 2016).

56. Gałecki, A.; Burzykowski, T. Linear Mixed-Effects Models Using R; Springer: New York, NY, USA, 2013.

57. Fox, J. Effect displays in R for generalised linear models. J. Stat. Softw. 2003, 8, 1-27. [CrossRef] 
58. Wickham, H.; Chang, W. Ggplot2: An Implementation of the Grammar of Graphics. 2015. Available online: http:/ / ftp.auckland.ac.nz/software/CRAN/src/contrib/Descriptions/ggplot.html (accessed on 11 August 2016).

59. Walko, R.L.; Band, L.E.; Baron, J.; Kittel, T.G.; Lammers, R.; Lee, T.J.; Ojima, D.; Pielke, R.A., Sr.; Taylor, C.; Tague, C. Coupled atmosphere-biophysics-hydrology models for environmental modeling. J. Appl. Meteorol. 2000, 39, 931-944. [CrossRef]

60. Kolka, R.K.; Sebestyen, S.D.; Verry, E.S.; Brooks, K.N. Peatland Biogeochemistry and Watershed Hydrology at the Marcell Experimental Forest; CRC Press Taylor \& Francis Group: Boca Raton, FL, USA, 2011.

61. Noh, N.J.; Shannon, J.; Bolton, N.; Davis, J.; Van Grinsven, M.; Pypker, T.; Kolka, R.; Wagenbrenner, J. Carbon dioxide fluxes from coarse dead wood in black ash wetlands. Forests 2018, in press.

62. Dinsmore, K.; Skiba, U.; Billett, M.; Rees, R. Effect of water table on greenhouse gas emissions from peatland mesocosms. Plant Soil 2009, 318, 229-242. [CrossRef]

63. Chimner, R.A.; Cooper, D.J. Influence of water table levels on $\mathrm{CO}_{2}$ emissions in a colorado subalpine fen: An in situ microcosm study. Soil Biol. Biochem. 2003, 35, 345-351. [CrossRef]

64. Leifeld, J.; Steffens, M.; Galego-Sala, A. Sensitivity of peatland carbon loss to organic matter quality. Geophys. Res. Lett. 2012, 39. [CrossRef]

65. Updegraff, K.; Pastor, J.; Bridgham, S.D.; Johnston, C.A. Environmental and substrate controls over carbon and nitrogen mineralization in northern wetlands. Ecol. Appl. 1995, 5, 151-163. [CrossRef]

66. Yavitt, J.B.; Williams, C.J.; Wieder, R.K. Production of methane and carbon dioxide in peatland ecosystems across north America: Effects of temperature, aeration, and organic chemistry of pent. Geomicrobiol. J. 1997, 14, 299-316. [CrossRef]

67. Best, E.P.H.; Jacobs, F.H.H. The influence of raised water table levels on carbon dioxide and methane production in ditch-dissected peat grasslands in the netherlands. Ecol. Eng. 1997, 8, 129-144. [CrossRef]

68. Ewel, K.C.; Cropper, W.P., Jr.; Gholz, H.L. Soil $\mathrm{CO}_{2}$ evolution in florida slash pine plantations. Ii. Importance of root respiration. Can. J. For. Res. 1987, 17, 330-333. [CrossRef]

69. Hanson, P.J.; Edwards, N.T.; Garten, C.T.; Andrews, J.A. Separating root and soil microbial contributions to soil respiration: A review of methods and observations. Biogeochemistry 2000, 48, 115-146. [CrossRef]

70. Edwards, N.T.; Harris, W.F. Carbon cycling in a mixed deciduous forest floor. Ecology 1977, 58, $431-437$. [CrossRef]

71. Burns, R.M.; Honkala, B.H. Silvics of North America; United States Department of Agriculture: Washington, DC, USA, 1990; Volume 2.

72. Costilow, K.; Knight, K.; Flower, C. Disturbance severity and canopy position control the radial growth response of maple trees (Acer spp.) in forests of northwest Ohio impacted by emerald ash borer (Agrilus planipennis). Ann. For. Sci. 2017, 74, 10. [CrossRef]

73. Thomas, K.L.; Benstead, J.; Davies, K.L.; Lloyd, D. Role of wetland plants in the diurnal control of $\mathrm{CH}_{4}$ and $\mathrm{CO}_{2}$ fluxes in peat. Soil Biol. Biochem. 1996, 28, 17-23. [CrossRef]

74. Nave, L.; Gough, C.; Maurer, K.; Bohrer, G.; Hardiman, B.; Le Moine, J.; Munoz, A.; Nadelhoffer, K.; Sparks, J.; Strahm, B. Disturbance and the resilience of coupled carbon and nitrogen cycling in a north temperate forest. J. Geophys. Res. Biogeosci. 2011, 116. [CrossRef]

75. Nuckolls, A.E.; Wurzburger, N.; Ford, C.R.; Hendrick, R.L.; Vose, J.M.; Kloeppel, B.D. Hemlock declines rapidly with hemlock woolly adelgid infestation: Impacts on the carbon cycle of southern Appalachian forests. Ecosystems 2009, 12, 179-190. [CrossRef]

76. Davis, J.C. Vegetation Dynamics and Nitrogen Cycling Responses to Simulated Emerald Ash Borer Infestation in Fraxinus nigra-Dominated Wetlands of Upper Michigan, USA; Michigan Technological University: Houghton, MI, USA, 2016.

77. Zehnder, A.; Stumm, W. Geochemistry and biogeochemistry of anaerobic habitats. In Biology of Anaerobic Microorganisms; John Wiley \& Sons, Inc.: New York, NY, USA, 1988; pp. 1-38.

78. Dunfield, P.; Knowles, R.; Dumont, R.; Moore, T.R. Methane production and consumption in temperate and subarctic peat soils: Response to temperature and PH. Soil Biol. Biochem. 1993, 25, 321-326. [CrossRef]

79. Moore, T.R.; Dalva, M. Methane and carbon dioxide exchange potentials of peat soils in Aerobic and Anaerobic laboratory incubations. Soil Biol. Biochem. 1997, 29, 1157-1164. [CrossRef]

80. Gauci, V.; Gowing, D.J.G.; Hornibrook, E.R.C.; Davis, J.M.; Dise, N.B. Woody stem methane emission in mature wetland alder trees. Atmos. Environ. 2010, 44, 2157-2160. [CrossRef] 
81. Erdmann, G.G.; Crow, T.R.; Ralph, M., Jr.; Wilson, C.D. Managing Black Ash in the Lake States; General Technical Report NC-115; US Dept. of Agriculture, Forest Service, North Central Forest Experiment Station: St. Paul, MN, USA, 1987; Volume 115.

82. Flower, C.E.; Gonzalez-Meler, M.A. Responses of temperate forest productivity to insect and pathogen disturbances. Annu. Rev. Plant Biol. 2015, 66, 547-569. [CrossRef] [PubMed]

83. Looney, C.E.; D'Amato, A.W.; Palik, B.J.; Slesak, R.A. Canopy treatment influences growth of replacement tree species in Fraxinus nigra forests threatened by the emerald ash borer in Minnesota, USA. Can. J. For. Res. 2016, 47, 183-192. [CrossRef]

84. Bolton, N.; Shannon, J.; Davis, J.; Grinsven, M.V.; Noh, N.J.; Schooler, S.; Kolka, R.; Pypker, T.; Wagenbrenner, J. Methods to improve survival and growth of planted alternative species seedlings in black ash ecosystems threatened by emerald ash borer. Forests 2018, 9, 146. [CrossRef]

85. Iverson, L.; Knight, K.S.; Prasad, A.; Herms, D.A.; Matthews, S.; Peters, M.; Smith, A.; Hartzler, D.M.; Long, R.; Almendinger, J. Potential species replacements for black ash (Fraxinus nigra) at the confluence of two threats: Emerald ash borer and a changing climate. Ecosystems 2016, 19, 248-270. [CrossRef]

86. Zehetgruber, B.; Kobler, J.; Dirnböck, T.; Jandl, R.; Seidl, R.; Schindlbacher, A. Intensive ground vegetation growth mitigates the carbon loss after forest disturbance. Plant Soil 2017, 420, 239-252. [CrossRef] [PubMed]

87. Hayhoe, K.; VanDorn, J.; Croley, T., II; Schlegal, N.; Wuebbles, D. Regional climate change projections for Chicago and the US great lakes. J. Great Lakes Res. 2010, 36, 7-21. [CrossRef]

(C) 2018 by the authors. Licensee MDPI, Basel, Switzerland. This article is an open access article distributed under the terms and conditions of the Creative Commons Attribution (CC BY) license (http://creativecommons.org/licenses/by/4.0/). 